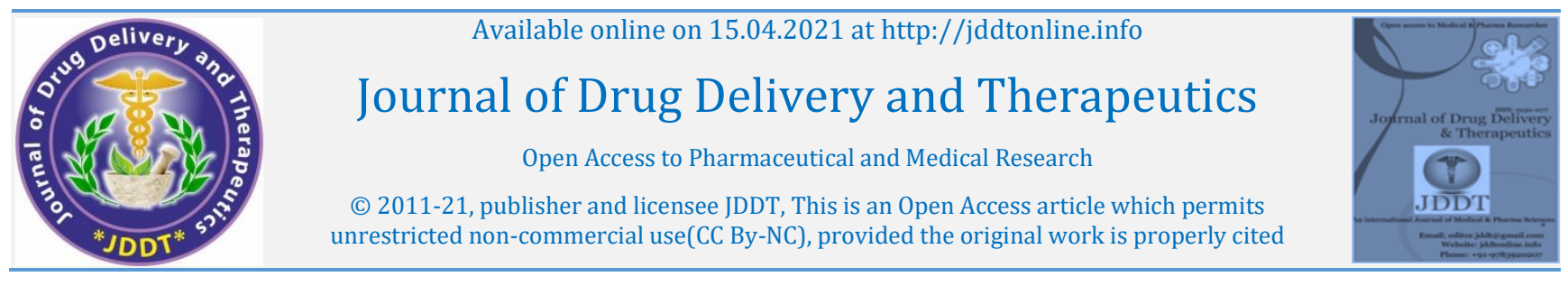

(C) 2011-21, publisher and licensee JDDT, This is an Open Access article which permits Access Full Text Article

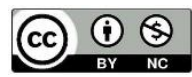

Review Paper

\title{
A comprehensive review on traditional uses, chemical compositions and pharmacology properties of Achyranthes aspera (Amaranthaceae)
}

\author{
Kapil Kumar Verma*, Akanksha Sharma, Hans Raj, Bhopesh Kumar \\ School of Pharmacy, Abhilashi University, Mandi-175028, Himachal Pradesh, India
}

\section{Article Info:

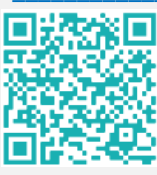 \\ Article History: \\ Received 09 Feb 2021 \\ Review Completed 16 March 2021 \\ Accepted 22 March 2021 \\ Available online 15 April 2021

\begin{abstract}
Cite this article as:
Verma KK, Sharma A, Raj H, Kumar B, A comprehensive review on traditional uses, chemical compositions and pharmacology Journal of Drug Delivery and Therapeutics. 2021; 11(2-s):PageNo.

DOI: http://dx.doi.org/10.22270/jddt.v11i2-s.4789
\end{abstract} properties of Achyranthes aspera (Amaranthaceae)}

*Address for Correspondence:

Kapil Kumar Verma, School of Pharmacy, Abhilashi University, Mandi-175028, Himachal Pradesh, India

\begin{abstract}
Achyranthes aspera plant is very useful for the cure and treatment of various diseases of human beings. Different parts of the plants is used to cure various diseases like leprosy, asthma, arthritis, wound, snakebite, dermatological diseases, cardiac disease, kidney stone, gynecological disorder, malaria, gonorrhea, pneumonia, dysentery, rabies, toothache, etc. Phytochemistry, pharmacological activities, diseases, traditional uses of the Achyranthes aspera may explain briefly in review articles with in-vivo and in-vitro studies. This article provided the complete latest information on the Achyranthes aspera which may include Phytochemistry, pharmacological activities, diseases, traditional uses, etc. Some extensions regarding Phytochemistry, pharmacological activities, diseases, traditional uses may explain in this review. Data may have the info about different activities of various diseases such as hepatoprotective, anticancer, anti-inflammatory, antiarthritic, thyroid-stimulating, antiperoxidative, abortifacient, antilaprotic, immunomodulators, contraceptives, etc. It may have many chemical constituents Glycosides, saponins, carbohydrates, alkaloids, cardiac glycosides, amino acid, ecdysterone, hentriacontane. Some chemical constituents which are Glycosides, saponins, carbohydrates, alkaloids, cardiac glycosides, amino acid, ecdysterone, and hentriacontane of the Achyranthes aspera used in high range throughout the world. There should be many investigations for these further clinical trials. This plant may be investigated on the next level for a novel drug system.
\end{abstract}

Keywords: Pharmacological activities, traditional uses, phytochemical constituents, clinical trials.

\section{INTRODUCTION}

Ayurveda is most used system from ancient time, as a medicinal purpose. Ayurveda is maximum known throughout the worldwide for cure and treatment of various diseases of human beings. It may provide a healthy and safest life. Nature gives many of medicinal plants which may be used in higher scale and most effective against any of diseases. There are many medicinal agents in nature which may be used from thousands of years. Natural medicinal plant may isolate and new property of the plant has been used for further medicinal investigation. From Ayurveda medicine was got achievements of ancient Indian civilization. Ayurveda may give importance to medicinal drugs and secondly to the physician which may give treatment to humans.

In Present years, interest in Ayurvedic system of the people increasing day by day because of its good effects and no side effects against the disease. By increasing population the demand of herbal drugs also increasing. All the herbal may formulate according to the Indian Pharmacopeia of Ayurvedic system. Maximum of herbal plants formulations used for their accuracy and efficacy, or easily available throughout the world. Focus on the plant is increasing per day .Green plant may use from the ancient times.These are healthier than that of the synthetic products with less toxic effects. Plants are safe, new and biodegradable drugs.

Herbal plants may use from the ancient time and also used for the antibacterial activity. All plants may have the medicinal properties. Antioxidative properties are involved in A. aspera plant. With presence of phenolic and flavonoids constituents it may antioxidative properties in it ${ }^{1}$. Natural antioxidants may protect the human from free radicals, and all the harmful disease like cancer, infections, cardiovascular diseases, and all chronic diseases etc ${ }^{2}$.Natural antioxidants may be good effective and have the less toxic effect than that of other components ${ }^{3,4}$. Synthetic antioxidants are only effective for the outsources oxidative products and used in pharmaceutical companies. This activity may have the good effect on human than of synthetic antioxidants and cure for all diseases on health care of the human ${ }^{5,6}$.

Achyranthes aspera belonging to family Amaranthaceae is an herb which may grows all over the worldwide. Traditionally known as Apamarga. It is an annually based plant. An erect herb which may have height around $2.0 \mathrm{~m}$ and $1000 \mathrm{~m}$ in height ${ }^{7}$.This plant is found in world Ceylon, Tropical Asia, Africa, Australia, America, and India. Achyranthes aspera is used for its medicinal property throughout the world ${ }^{8,9}$.Leaves of the plant elliptic ovate and $22 \mathrm{~cm}$ long and 
2.5 in broad, Stems are square in shape, around $30 \mathrm{~cm}$ long florescence with white or red flowers $7 \mathrm{~mm}$ broad. The flowers having growth in summer.

Name of Achyranthes aspera in various languages:

$\begin{array}{ll}\text { Arabic } & \text { Atkumah } \\ \text { Bengali } & \text { Apang } \\ \text { English } & \text { Rough Chaff } \\ \text { Guajarati } & \text { Aghedo } \\ \text { Hindi } & \text { Latjira } \\ \text { Kannada } & \text { Uttatane } \\ \text { Malayalam } & \text { Kadaladi } \\ \text { Punjabi } & \text { Kutri } \\ \text { Sanskrit } & \text { Apamarga } 10\end{array}$

Achyranthes aspera shows different activities of various diseases such as hepatoprotective 11 , anticancer 12 , antiinflammatory, anti-arthritic 13, thyroid stimulating, antiperoxidative, abortifacient, anti laprotic, immunomodulators ${ }^{14}$,contraceptives ${ }^{15}$ etc. Different parts of the plants is used to cure various diseases like leprosy, asthma, arthritis, wound, snake bite, dermatological diseases, cardiac disease, kidney stone, gynecological disorder, malaria, gonorrhea, pneumonia, dysentery, rabies, toothache etc. There are many phytochemicals constituents present in Achyranthes aspera which may use to cure various ailments. The constituents are alkaloids, saponins, glycosides, ecdysterone, cardiac glycosides etc.

\section{MORPHOLOGY}

Achyranthes aspera is an annual herb which may use for this medicinal property throughout the world. Leaves are simple 1-3 feet from stem ${ }^{16}$, Stamens are double in shapes ${ }^{17}$, Stomata are animosities ${ }^{18}$, embryology is seen, indorse type of anther, many covering structures. Vascular and medullar bundles also founds, and cambium 19,20.

Root - Cylindrical Shape $1.0 \mathrm{~cm}$ in diameter. Divided into two parts secondary and tertiary roots.

Leaves - Simple and ovate, Opposite, velvety, Elliptical.

Flowers - Bracteolate, green or red, bracteates, spikes shape.

Petals - 2 petals in spikes green or white coloured.

Fruits - fruits stored in utricle and dry.

Seeds - smoothed and curved embryo, Alnuminous.

Androecium - 5 stamens with corolla lobes.

Gynoecium- ovary is superior and having 2 syncarpous ${ }^{21}$.

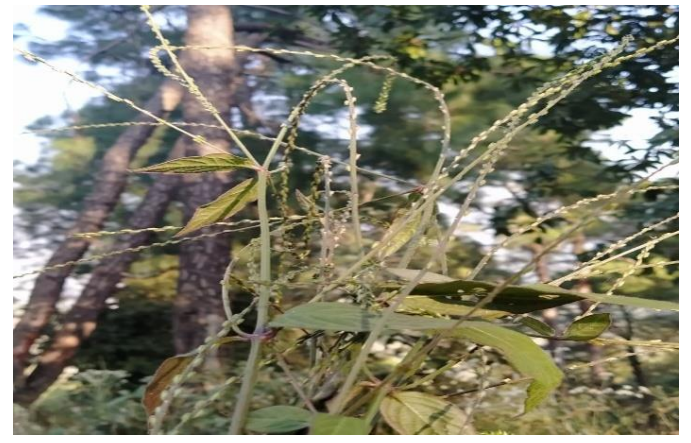

\section{DISTRIBUTION}

Apamarga found in whole world in different regions .Mostly found in tropical and warmer regions of the world ${ }^{22}$. This plant is mainly found in world Ceylon, Tropical Asia, Africa,
Australia, America, and India 23. It is found in India state Himachal Pradesh as a Shivbari sacred grove 24,25. Medicinal plant used in Ayurveda system. A vegetation of Apamarga also found in Karachi and Pakistan ${ }^{26}$.

\section{Taxonomical Classification}

Botanical Name Achyranthes aspera

Kingdom Plantae

Divisions Mangolipside

Family Amaranthaceae

Genus Achyranthus

Species Aspera

\section{USES}

Achyranthes aspera has been used for ayurvedic medicines. Used for diuretics, dermatological disorders, gynecological disorders 27 , induce labor pain, genitalia ${ }^{28}$, etc. Mainly used for the renal leprosy, cough ${ }^{29}$, scrofula, fistula, skin rash, nasal infection ${ }^{30}$,chronic malaria, fever, asthma ${ }^{31}$,piles, snake bites, diarrhea, cold, menstrual disorders ${ }^{32}$, astringent for wound healing, cancer ${ }^{33}$, etc. All parts of the plant may useful for the diseases, Leaves, stem, bark, all have medical properties ${ }^{34}$.For kidney stone and skin eruptions, allergy ${ }^{35}$, snake bite, diabetes, renal failure. Many of the formulations are made for different diseases juices also treat ophthalmic and dysentery ${ }^{36}$.Also used for the antifertility, induced the abortion, bleeding, renal complications, scorpion bite, boils, hemorrhoids, rheumatism, itches, toothache, nervous problems, hysteria etc. ${ }^{37}$ From ancients times it may be used for the temple worship For Ganesh Chathurathi, In Shiva pujan leaves are used and known to be good sign for luck ${ }^{38}$. Plant have ash used to treat ulceritis 39 . Roots used for vomiting. Also used to cure pneumonia by boiled the leaves of the plant ${ }^{40}$. Tranquilizing properties also occurs ${ }^{41}$. Used in different formulations like soaps, perfumes, dental products, prepared food and beverages etc. ${ }^{42}$

\section{PHYTOCHEMICAL SCREENING}

Medicinal plants may used for various disease which may have different constituents involved. They constituents are responsible for curing the diseases either that is chronic or short term. Some of secondary metabolites present alkaloids, phenols, glycosides, tannins, saponins, terpenoids, flavonoids etc. Some of essential oils which have therapeutic agents. Most of the constituents may present and used for the diuretic, purgative, laxative, hepatoprotective, antiasthmatic, cough, diarrhea, ulcers, piles etc.

Achyranthes aspera may have many chemical constituents which may responsible for many diseases. Glycosides, saponins, carbohydrates, alkaloids, cardiac glycosides, amino acid, ecdysterone, hentriacontane may present in the plant 9 . It may have saponin A and B. Oleonalic acid extracted from the roots of the plant. Some of sugars compound also present such as L-rhamnose, D-glucose etc. ${ }^{43}$. Amino acid, ecdysterone, hentriacontane etc. may extract or isolated from the seeds of the plant. All the parts of the plant may have many of constituents known as dihydroxyketone, 36,37-dihydorxypentacontan-4-on and tricontanol,27cyclohexylheptaconsane-7-ol and 16-hydrox-26-methyl heptacosane-2-on are extracted from the shoots of the Apamarga ${ }^{44}$. Yellow semi solid formulation may extract from the petrol extract of shoots by this the aliphatic alcohol that is 17-pentatriacontanol may contain ${ }^{45}$. Methanol extract of the plant may Ecdysterone and phytoecdysone may contain and show the reaction by its colour ${ }^{46}$. 


\begin{tabular}{|c|l|}
\hline Plant Parts & \multicolumn{1}{|c|}{ Chemical Constituents } \\
\hline Roots & $\begin{array}{l}\text { Oleanolic Acid, Amino acid, Steroids, Alkaloids, Triterpenoids, Coumarins, Ecdysterone, Ionokosterone, } \\
\text { Rubrosterone, Oligosaccharides, Polysaccharides, Achyranthine, Glycosides, Tannins }\end{array}$ \\
\hline Seeds & Linoleic acid, Oleic acid, Palminitic acid, Stearic acid, Behenic \\
\hline Shoots & $\begin{array}{l}\text { Dihydroxyhenpenta Triacontanol, 27-cyclohexyl heptacosane 7-ol } \\
\text { 17-penta-triancontanol, 16-hydroxy-26-Methyl heptacosane-2-1.21 }\end{array}$ \\
\hline
\end{tabular}

Apamarga is also a good source of minerals and vitamins. It may also contains magnesium, sodium, phosphorous, potassium, chloride etc. In Vitamins Vitamin-B and Vitamin$\mathrm{C}$ are present in heavy amount. Generally minerals, vitamins, proteins, fibers, carbohydrates etc. may found. Rich source of fibers and flavonoids also present which give antioxidant properties. Anti-cancerous compounds may present and listed in USDA for this cancer activity. Essential oils may found in less amount and harmful for pregnant lady ${ }^{47}$. It may contain volatile oil such as tritricontane, betane, achyranthene and long chain alcohols. Apamarga seeds may contains oils that shows presence of fatty acids ${ }^{48}$. The essentials which may found in the plant are 3-acetoxy- 6 benzoyloxyapangamide, $\beta$ sterol, trans-13-doxynoeic acid, $\mathrm{n}$ hexacos-14-enoic, tetracontanol, strigmasta, tricosanone. Bisdesmosidic saponins also present in the plant $\beta$-dglucopyranosyl, $\quad 3 \beta-[0-\alpha-1-r h a m n o p y r a n o s y l-(1 \rightarrow 3)-0-\beta-$ dglucopyranuronosyloxy] $\beta$-dglucopyranosyl3 $\beta$ - $[0-\beta-d-$ galactopyranosyl-(1 $\rightarrow 2) \alpha$ dglucopyranuronosyloxy] machaerinate, $\beta$-D-glucopyranosyl ester of $\alpha$-L-

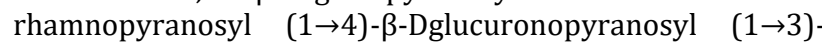
oleanolic acid and $\beta$-Dglucopyranosyl ester of $\alpha$-Lrhamnopyranosyl $(1 \rightarrow 4)-\beta$-Dglucopyranosyl $(1 \rightarrow 4) \quad \beta$-Dglucuronopyranosyl $(1 \rightarrow 3)$ oleanolic, sapogenin, etc 49 .

(n)




(n)

\section{PHARMACOLOGICAL ACTIVITIES}

Anticancer Activities- Various investigation of Achyranthes aspera show effect against cancerous activities. This investigation may test on Swiss albino mice which may treated with the mineral oils. Flowers and leaves part were tested for antitumor activities. The crude extract of the plant doses may give to the mice at different concentration. The ether extract may give the positive effects against tumors more than other extracts ${ }^{50}$.

Antimicrobial Activities-For antimicrobial activity the plant may extract out from the petroleum ether, methanol etc. and treated with dimethyl sulphoxide at different concentrations. The root extract of the plant may show the less effect on gram positive bacteria and show high effect against the gram negative bacteria. At different concentration or different extracts may give antimicrobial activity and antifungal activity also 51 .

Anti-diabetic Activities-52 Ethanolic extract may formed to check the diabetes mellitus and tested on albino ice which may have diabetes. By checking random sugar it may have the high glucose level of the albino rat. The ethanol extract may give to mice and it may show effect against the diabetes 51.

Diuretic Activities-Albino rats may used for this activity, they treated with the extract at different doses 10,30 and $50 \mathrm{mg}$ by Intraperitoneol routes. And the results found that extract of the plant may give the effects against the diuretic and also increase the flow of the urine ${ }^{53}$.

Hepatoprotective activity- Ethanolic extract of the seed of the plant may test in rats. Carbon tetrachloride doses may induce the liver administered to rats. Serum level may test of rats and some of inhibition takes place then the ethanolic extract administered to rats with standard drug silymerin. This may results the good effects hepatoprotective activity 54.
Antioxidant activities-Apamarga may have many of constituents which may have antioxidants properties. By all these constituents the plant may have antioxidant effects. It may investigate by methanolic extract of the plant including DPPH methods for antioxidant. Some of flavonoids may present in constituents of the flower and leaves part of the Apamarga which gives effect of antioxidants 55 .

Anti-inflammatory activities-This plant may also have the inflammation inhibiting properties by presence of some constituents in it. In this ethanolic extract of the plant may induced to the rats model at different concentrations which have inflammation. After some days the inflammation of rats may decreases then the results may shows that the plant may have also anti-inflammatory effects 56 .

Antiarthritic activity- Ethanolic extract of the plant with standard drug diclofenac sodium may use in this investigation. The flower part may use. Different concentration of ethanolic extract and standard drug of diclofenac may induce the arthritics effect. Constituents which may use for this are tannins and flavonoids 57 .

Cardiovascular activities- This plant may also investigate the cardiac diseases. By presence of the Achyranthine, saponins, alkaloids may leads to cure the heart rate, lowering Blood pressure, depression of heart, increasing rate of respiration in dogs. Hence the results may show the cardiovascular activities of Achyranhtesaspera ${ }^{58}$.

Prothyrodic activity-Rats may used to investigation for this activity. The plant extract of the plant may decrease the thyroid in rats due to tannins and saponins. It also decreases lipid peroxidation 59 .

Immuno Modulatory activity-From many investigation Immuno Modulatory activities may found in Apamarga. Increase of induction of OVA-specific antibody response in a dose. An hydro alcoholic extract reported to stimulate the immune system and increase the phagocytic. Then its shows the Immuno Modulatory effects ${ }^{60}$. 
Anthelmintic Activities-This study may test on earthworm. By using ethyl acetate, ethanol and crude extrat of the plant at various concentration. Albendazole may used as a standard. Ethanolic extract may show the good effects against the anthelmintic activity 61 .

Antiviral Activities- Invitro methods investigated for antiviral activities. Methanolic extract of leaves may inhibits the virus Epstein-Barr by antigen which may induced the tumor. Non polar compounds may exist in this which may leads inhibitory activity ${ }^{12}$.

Antiamoebic and Anti fertility-Decoction procedure may lead to test the antifertility activity. Root part of the plant may use to these activities, buttermilk as antifertility drug 62 . And it also shows anti-spermicidal activity 63 .

Blood Pressure- Root part of the plant may leads to decrease B.P. while the higher B.P. takes place due to chloroform extract 64 .

Post Coital antifertility activity- This investigation may test on rats, ethanolic extract of the drug may be used which may showed the implantation and didn't deliver litters. Anlaparotomy may apply on rat at $25^{\text {th }}$ day which may show the implantation and reabsorption.It proved that ethanolic extract of the plant may have antifertility activity ${ }^{7}$.

Estrogenic Activity-The invitro method on immature rats was investigated by the ethanol extract of the plant.It may increase the effect uterine weight in rats. The weight of uterus is high checked by the uterotrophic potency, than ethinylestradiol. The potency of uterotrophic may increase and decrease of uterus in control rats. Uteri may inflated in estrous uterus. Rats which may treat with the extract may open vagina ${ }^{7}$.

Larvicidal Activity- Root extract may used to show more larvicidal activity on Boophillismicroplust. Saponins may tested against Aedesegyptii. The ethyl extraction may be show positive against Aedespictusmosquitolarvae. Essential oil of leaf of A.aspera may extract out were showed the larvicidal activity and the extract of the plant may positive effect against Aedesegyptii65.

Hypolipidemic Activity-Extract of aspera may shows effects against rats. Diseases lower cholesterol, phospholipids, Serum cholesterol, triglycerides, total lipids etc. may cure by the alcoholic extraction of the plant. Rats which may have the hyperlipidemia was tested for this procedure. Sesame oil which may present may show the lipid peroxidation. Rats may be used for this till 30 days by TC, PL, and CG etc. Extract administered to rats at different concentration and show the effect against the lipids. Excretion from faces and chloric acid increases by these doses. By low absorption it may show the action against cholesterol 66 .

Analgesic and Antipyretic Activity-This may be investigate by brewers induced methods by using aspirin as a standard drug. Ethanolic extract of $A$. aspera may study. Leaves and Seeds extract may have analgesic activities. Roots also have the analgesic activities which may show in the albino rats by using the aspirin as a standard drug. The different doses may administer to the rats which showed the more effect of analgesics ${ }^{67}$.

Wound Healing Activity- Some of wounds may treat with methanol extract ointment. Ethanolic extract of $A$. aspera may also have the wound healing activity. Excision and incision wound model may was studied for effect of the drug against Wound Healing Activity 68 .
Cardiac Activity-Saponin may present into the plant which give cardiac activity. When the heart may increase the contraction and intact hypodynamic, then the leaf part of the plant may investigate to Cardiac activity. Achyranthine may show the increasing and decreasing the rate of the heart rate, contraction of the heart, depression of heart etc. Saponins present in the plant may show the effect against the cardiac diseases 69 .

Renal Disorders-Calcium oxalate, calcium carbonate, calcium phosphate may found in urinary stones. Methanolic extract of the plant may use for inhibit this and prevent nephrotoxicity in rats .Roots of the plant may used for the urine stones and it may show the good effects against calcium oxalate, calcium carbonate, calcium phosphate etc ${ }^{70}$.

Spermicidal Activity- Roots of the plant may used to report activity of spermicidal in humans and rats too. Chloroform extracts, hydroethanolic extracts show effect against the spermicidal. Sperm vitality, sperm immobilization, acrosome status, nuclear chromatin may involved into this studied 71 .

Antidandruff Activity-Coumarins a constituent may present into this plant may give the property of antidandruff. It may have polyherbal oil by the methanolic extract of the plant. Constituent also act against the growth of Pityrosorumovale and reduce the dandruff 68 .

Antidepressants Activity- Rats administered by the various dose concentrations of Methanolic extract of the plant. Oral dose of the extract may effective to reduce the depression and immobility time 72 .

\section{Miscellaneous pharmacological activities-}

Achyranthes aspera is used traditionally for medicinal uses all over the world. This plant may treat many disorders like fever, malarial, asthma, dysentery, asthma, diabetes etc ${ }^{73}$. It may used for many pharmacological activities. All the parts of the plant may used to treat various diseases 74 . Many of Phytoconstituents may present in the leaf, root, leaves, flower extract of the plant ${ }^{75}$. All the extracts may give effects on the different activities such as, antioxidants, anthelmintic, antiviral, antifertility, blood pressure, cardiac, diuretics etc ${ }^{8}$. This medicinal plant may used to food and beverages, perfumes, soap preparation etc ${ }^{76}$. Many of constituents responsible for these activities. Tannins, Saponins, Flavonoids, proteins, sugars, triterpenoidsetc ${ }^{77}$ used for antioxidants 78 . This antioxidant activity is affected through the methanolic extract of the A. aspera ${ }^{79}$. DPPH assay may use to investigate the antioxidant property ${ }^{80}$. Phenolic compounds give the antioxidant properties for the plant 81 . Ovulation may block through the estrogenic property which may affects pituitary by $\mathrm{FH}$ and $\mathrm{LSH}^{82}$. Ant estrogenic activity may takes place which is responsible formation of ovum. A. aspera may also use in gynecological disorders ${ }^{83}$. Also used in leprosy, bronchial infections, cough etc. For carcinogenic diseases it may give better effects. It may helps to decrease the thyroid hormones ${ }^{84,85}$.

\section{CONCLUSION}

Ayurveda may give importance to medicinal drugs and secondly to the physician which may give treatment to humans. Achyranthes aspera belonging to family Amaranthaceae is an herb which may grows all over the worldwide. Traditionally known as Apamarga. Complete parts of the A. aspera may study thoroughly and found that drug used widely as a medicinal plant. This plant is found in world Ceylon, Tropical Asia, Africa, Australia, America, and India. Achyranthes aspera shows different activities of various diseases such as hepatoprotective, anticancer, ant 
inflammatory, antiarthritic, thyroid stimulating, antiperoxidative, abortifacient, anti laprotic, immunomodulators, contraceptives, Larvicidal, spermicidal, antidandruff, analgesic, hypolipidemic, hypoglycemic, cardiovascular, nephrotoxicity. Different parts of the plants is used to cure various diseases like leprosy, asthma, arthritis, wound, snake bite, dermatological diseases, cardiac disease, kidney stone, gynecological disorder, malaria, gonorrhea, pneumonia, dysentery, rabies, toothache etc. There are many phytochemicals constituents present in Achyranthes aspera which may used to cure various ailments. The constituents are alkaloids, saponins, glycosides, ecdysterone, cardiac glycosides, fatty acids like Myristic acid, palmitic acid, stearic acid, arachidic acid, oleic acid, linoleic acid. All investigation of the plant may have clinical trials and research more things about this. This plant may be investigated on the next level for a novel drug system.

\section{REFERENCES}

1. Dawidowicza AL, Wianowska, D. The antioxidant properties of alcoholic extracts from Sambucusnigra L. (Antioxidant properties of extracts). LWT. 2006; 39:308-315.

2. Lai LS, Chou ST. Studies on the antioxidant activities of Hsiantso (Mesonaprocumbens Hemsl). J. Agric. Food Chem. 2001; 49:963-968.

3. Liscovitch M, Lavie. Cancer multidrug resistance: a review of recent drug discovery research. I Drugs. 2002; 5:349-355.

4. Lizcano LJ, Bakkali F. Antioxidant activity and polyphenol content of aqueous extracts from Colombian Amazonian plants with medicinal use. Food Chem.2010; 119:1566-157

5. Liu RH. Health benefits of fruit and vegetables are from additive and synergistic combinations of phytochemicals. Am. J. Clin. Nutr.2003; 78:517S-520S.

6. Djeridane A, Yousf MN. Antioxidant activity of some Algerian medicinal plants extracts containing phenolic compounds. Food Chem. 2006; 97:654-660

7. Vasudeva N, Sharma SK. Post-coital antifertility activity of Achyranthes aspera Linn. Root, J. Ethno pharmacological, 2006; 107:179- 181

8. Misra TN, Singh RS, Pandey, HS, Prasad, C, Singh, BP. Antifungal essential oil and a long chain alcohol from Achyranthes aspera,Phytochemistry, 1992; 1811-1812.

9. Hariharan V, Rangaswami S, Structure of saponines A and B from the seeds of Achyranthes aspera Phytochemistry 1970; 409-414.

10. Prasad PVV, Subhaktha PKJP. Apamarga (Achyranthes aspera Linn.) A Medico - Historical ReviewBull. Ind. Inst. Hist. Med. 2001; Vol. XXXI - 11 to 24.

11. Bafna AR, Mishra SH. Effect of methanol extract of Achyranthes aspera Linn. On rifampicin-induced hepatotoxicity in rats. Ars Pharmaceutical 2004; 343-351.

12. Chakraborty A, Brantner A, Mukainaka, T, Nobukuni, Y, Kuchide M, Konoshima T, Tokuda H, Nishino H. Cancer chemopreventive activity of Achyranthes aspera leaves on Epstein-Barr virus activation and two-stage mouse skin carcinogenesis. Cancer Lett. 2002; 177:1-5.

13. Gokhale AB, Damre AS, Kulkami KR, Saraf MN. Preliminary evaluation of anti-inflammatory and anti-arthritic activity of S. lappa, Achyranthesspeciosa and Achyranthes aspera.Phytomedicine. 2002; 9:433-437.

14. Rao G. Immunomodulatory activity of Achyranthes aspera on the elicitation of antigen specific murine antibody response. Int. J. Pharmacognosy 2002; 40:175-178.

15. Wadhwa V, Singh MM, Gupta DN, Singh C, Kamboj VP. Contraceptive and hormonal properties of Achyranthes aspera in rats and hamsters. Plantae Med. 1986; 3:231-233.

16. Joshi AC. Dedoublement of stamens in Achyranthes aspera Linn. J. Indian bot. Soc. 1932; 11:335-339.

17. Kajale LB. Embryology of Achyranthes aspera Linn. Proceedings: Plant Sciences.1937; 5(5):195-205.

18. Pandya SM, Pathak VS. Seed dormancy imposed by covering structures in Achyranthes aspera, Geobios, (Jodhpur). 1980; 7:74-76.
19. Perveen A, Abid R, Fatima R. Stomatal types of some dicots within flora of Karachi, Pakistan, Pak. J. Bot. 2007; 39(4):10171023.

20. Islam MSU, Abid R, Qaiser. Anther types of dicots within flora of Karachi, Pakistan. Pak. J. Bot.2008; 40(1):33-41.

21. Dr. Mohammad atiqur Rahman. Phytochemical and experimental studies on apamarga WSR to female antifertility, Bijapur.2009; 9-11

22. Hooker JD. The Flora of British India, 4, L. Reeve \& Co. Ltd, Kent.1885; 713-730.

23. Prain D. Bengal Plants, Botanical Survey of India, Calcutta. 1963; 646-655.

24. De, Lange PJ, Scofield RP, Greene T. Achyranthes aspera (Amaranthaceae), a new indigenous addition to the flora of the Kermadec Islands group. New Zealand J. Bot. 2004; 42:167-173.

25. Jaryan V, Uniyal SK, Gopichand Singh R.D., Lal B, Kumar A, Sharma V. Role of traditional conservation practice: highlighting the importance of Shivbari sacred grove in biodiversity conservation, The Environmentalist. 2009; 30(2):101-110.

26. Khan D, Shaukat SS, Ismail S. Structure composition and pattern in Achyranthes aspera L. dominated ruderal vegetation in the suburbs of Karachi Pakistan, Pakistan Journal of Botany. 1987; 19:157-174.

27. Nadkarni K. Indian Materia Media, III Ed., I, Popular Book Depot, Bombay. 1954; 21.

28. Jayaweera DMA. Medicinal used plants in Ceylon, Part IV. Colombo, Sri Lanka, National Science Council of Sri Lanka1982; 234-236.

29. Khan AV, Khan AA. Ethnomedicinal uses of Achyranthes aspera. (Amaranthaceae) in management of gynecological disorders in western Uttar Pradesh (India), The Journal of Reproductive and Fertility. 2006; 43(1):127-129.

30. Shukla R, Chakravarty M, Gautam MP. Indigenous medicine used for treatment of gynecological disorders by tribal of Chhattisgarh, India, Journal of Medicinal Plants Research. 2008; 2(12):356-360.

31. Bhattacharjee SK, De LC. Medicinal herbs and flowers, Awishkar Publishers and distributes, Jaipur (India).1991.

32. Selvanayagam ZE, Gnanavendan SG, Balakrishnan K, Rao RB,1994.Antisnake venom botanicals from Ethnomedicine. J. Herbs Spices Med. Plants.1994; 2:45-100.

33. Borthakur SK, Gowswami N. Herbal remedies from Dimoria of Kamrup district of Assam in northeastern India, Fitoterapia.1995; 66:333-340.

34. Singh V. Traditional remedies to treat the asthma in the North West and Trans-Himalayan region in J. and K. state, Fitoterapia. 1995; 66:507-509.

35. Bhattacharjee SK. Handbook of Medicinal Plants, 3rd ed., Pointer Publisher, Jaipur. 2001; 11.

36. Ghani, A. Medicinal plant of Bangladesh with chemical constituents and uses, 2nd ed., Asiatic Society of Bangladesh, Dhaka. 2003; 71-72.

37. Aziz A, Rahman M, Mondal AK, Muslim T, Rahman A, Quader A 3Acetoxy-6-benzoyloxyapangamide from Achyranthes aspera, Dhaka Univ. J. Pharm. Sci.2005;4(2):113-116.

38. Jain S. Kapoor S. Divine botany-universal and useful but under explored traditions. 2007.

39. Sujatha K. Kavitha K. Manoharan S. Assessment of invitro antiarthritic activity of achyranthesaspera Linn. 2014.

40. Alam M, Karim M, Khan SN. Antibacterial activity of different organic extracts of Achyranthes aspera and Cassia alata. Journal of scientific research. 2009; 1(2):393-398.

41. Shibeshi W, Makonnen E, Zerihun LA., Debella. Effect of Achyranthes aspera L. on fetal abortion, uterine and pituitary weights, serum lipids and hormones. African health sciences.2006; 6(2):108-112.

42. Kumar PS, Sucheta S, Deepa VS, Selvamani PS, Latha Antioxidant activity in some selected Indian medicinal plants. African Journal of Biotechnology. 2008; 7(12).

43. Batta AK, Rangaswami S. Crystalline chemical components of some vegetable drugs Phytochemistry. 1973; 12:214-6

44. Banerji A, Chadha MS. Insect moulting hormone from Achyranthes asperaPhytochemistry. 1970; 9:1671

45. Banerji A, Chintalwar GJ, Joshi NK. Isolation of ecdysterone from Indian plants Phytochemistry. 1971; 10:2225-6

46. Misra TG, Singh RS, Pandey HS. Two long chain compounds from Achyranthes asperaPhytochemistry. 1993; 33 (1):221-3 
47. Dey A. Achyranthes aspera L: phytochemical and pharmacological aspects. International journal of pharmaceutical sciences review and research. 2011; 9(2):72-82.

48. Singh BR, Yadav S, Singh S, Brind L. Pharmacognostic investigations of Achyranthes aspera Linn. International Journal of Ayurvedic Medicine. 2012; 2(4).

49. Srivastav S, Singh P, Mishra G, Jha K, Khosa R. Achyranthes aspera -An important medicinal plant: A review. J Nat Prod Plant Resource. 2011; 1(1):1-14.

50. Subbarayan PR, Sarkar M, Impellizzeri S, Raymo F, Lokeshwar, BL, Kumar P, Agarwal RP, Ardalan B. Anti-proliferative and anticancer properties of Achyranthes aspera: specific inhibitory activity against pancreatic cancer cells. Journal of ethnopharmacology.2010; 131(1):78-82.

51. Kaur M, Thakur Y, Rana R. Antimicrobial properties of Achyranthes aspera. Ancient science of life. 2005; 24(4):168.

52. Naidu KC. Anti-diabetic plants in India and herbal based antidiabetic research. Daya Books. 2003.

53. Asif M, Jabeen Q, Atif M, Majid AMSA, Qamar-Uz-Zaman M. Diuretic Activity of Achyranthes aspera Linn Crude Aqueous Extract in Albino Rats. Tropical Journal of Pharmaceutical Research. 2014; 13(12):2039-2045.

54. Manjunatha B., Abhilash N, Hegde V, Suchitra M, Vidya S. Hepatoprotective potency of Achyranthes aspera: An in-vivo study. International Journal of Pharmaceutical and Phytopharmacological Research. 2012; 1(1):387-390.

55. Beaulah A, Sadiq M, Santhi J. Antioxidant and antibacterial activity of Achyranthes aspera: An in vitro study. Annals of Biological Research. 2011; 2(5):662-670.

56. Vetrichelvan T, Jegadeesan M. Effect of alcohol extract of Achyranthes aspera Linn. on acute and sub-acute inflammation. Phytotherapy research.2003; 17(1):77-79.

57. Sujatha K, Kavitha K, Manoharan S. Assessment of in-vitro antiarthritic activity of Achyranthes aspera linn.2014.

58. Bagavan A, Rahuman AA, Kamaraj C, Geetha K. Larvicidal activity of saponin from Achyranthes aspera against Aedesaegypti and Culexquinquefasciatus (Diptera: Culicidae). Parasitology research. 2008; 103(1):223-229.

59. Khan AV, Khan AA. Ethnomedicinal Uses of Achyranthes aspera L. (Amarantaceae) in Management of Gynecological Disorders in Western Uttar Pradesh (India). Ethnobotanical Leaflets. 2005(1):11.

60. Vasudeva YR, Duddukuri GR, Sunil BG, Athota RR Immunomodulatory activity of Achyranthes aspera on the elicitation of antigenspecific murine antibody response. Pharmaceutical Biology. 2002; 40(3):175-178.

61. Esther J, Sangeetha N, Balabhaskar R, GayathriGunalan. In Vitro Anthelmintic Activity of Achyranthes aspera Linn. (Whole Plant) Against Pheretimaposthuma Esther et al. J Res Sid Med. 2018; (1):68-71.

62. Ali M, orient J Chem.1993; 9:84.

63. Pakrashi Basak B, Mookerji N. Search for antifertility agents from indigenous medicinal plants. Indian J. med. Res.1975; 85.

64. Paul D, Bera S, Jana D, Maiti R, Ghosh, D. Contraception 2006. 73, 284. 89. Anantha D. In vitro anti helminthic activity of aqueous and alcoholic extracts of Aervalanata seeds and leaves. J PharmaceutSci Resc. 2010; 2(5):317-321.

65. Chungsamarnyart N, Jiyajinda S, Jangsawan W. Larvicidal effect of plant crude extracts on the tropical cattle tick Boophilusmicroplus. Kasetsart J. 1991; 25:80- 89.
66. Priya K, Krishnakumari S. Phytochemical analysis of Achyranthes aspera and its activity on sesame oil induced lipid. peroxidation. Ancient Science of Life. 2007; 27(1):6-10.

67. Kumar H, Singh D, Kushwaha SKS, Gupta AK. Comparison of leaf and root extract of Achyranthes aspera for its analgesic activity. Der Pharmacia Lettre. 2009; 1(2):193-198.

68. Barua CC, Talukdar A, Begum SA, Buragohain B, Roy JD. Antidepressant like effects of Achyranthes aspera Linn. in animals models of depression. Pharmacology. 2009; 2:587-594.

69. Jayakumar T, Sridhar MP, Bharath Prasad, TR, Ilayaraja M, Govindasamy S. Experimental studies of Achyranthes aspera (L) preventing Nephrotoxicity induced by lead in Albino rats. J Health Science. 2009; 55(5):701-708.

70. Anantha D. In vitro anti helminthic activity of aqueous and alcoholic extracts of Aervalanata seeds and leaves. J PharmaceutSci Resc.2010; 2(5):317-321.

71. Shibeshi W, Makonnen E, Zerihun L, Debella A. Effect of Achyranthes aspera L. on foetal abortion, uterine pituitary weights serum lipids and hormones. African Health Science.2006; 6(2):108-112.

72. Singh N, Mrinal, Sharma P, and Kumar V, Gupta A. A Review on Pharmacological Aspects of Achyranthes Aspera International Journal Pharmacognosy Chinese Med 3(4):000188.

73. Gupta SS, Bhawat AW, Ram, AK. Cardiac stimulant activity of saponin of Achyanthesaspera (Linn) .J. Med. Res. 1972; 60:462471.

74. Mac Callum B. As cited by Solamann, T., in a manual of Pharmacology and its applications to therapeutics and toxicology, 8th Ed. Philadelphia London: W. B. Saunders Company. 1957; 667.

75. Buxiang S, Fukuhara M. Toxicology, 1997; 122: 61.

76. Sahav MR, Hasan SMR, Akter R, Hossain MM, Alam MS, Alam MA, Mazumder MEH. In Vitro Free Radical Scavenging Activity Of Methanol Extract Of The Leaves OfMimusopselengi Linn, Bangl, J. Vet. Med. 2008; 2(6):197-202.

77. Hawiaran V, Rangaswami S. Structure of saponins A and B from the seeds of Achyranthes aspera, Phytochemistry. 1970; 9:409414.

78. Shahidi F, Janitha PK, Wanasundara PD. Phenolic antioxidants, CRC CritRev.FoodSci Nutr.1992; 1(32):67-103.

79. Brinker F. Inhibition of endocrine function by botanical agents, Anti gonadotropic activity. British Journal of Phytotherapy. 1997; 4:123- 145 .

80. Gark SK, Mathur VS, Chaudhary RR. Screening of Indian Plants for anti-fertility activity. Indian Journal of Experimental Biology.1978; 16:107-118.

81. Prakash AD, Sexena V, Shukala S. Contraceptive potency of Puereria tuberose DC and its hormonal status. Acta European Fertility. 1985; 161:59-65.

82. Shukla S, Mathur R, Rakish AD. Effect of butanolic extract of Puerariatuberosa DC on estrus cycle of adult rats. Indian Journal of Pharmacology.1988; 19:48-53.

83. Brown JE, Rice-Evans CA. Luteolin rich artichoke extract protects low dysentery lipoprotein from oxidation in vitro, Free radical. Res. 1998; 29:247-255.

84. Shafique S, Javaid A, Bajwa R, Shafiqe S. Biological Control of Achyranthesaspera and Xanthium Strumarium in Pak.J.Bot. 2007; 7(39):2607-2610.

85. Thilagavathi G, Kannaian T. Application of prickly chaff (Achyranthaspera) Leaves as herbal antimicrobial finish for cotton fabric used in healthcare textile, Natural product radiance. 2008; 4 (7):330-334. 